\title{
Microclimate numerical simulation to obtain the minimum safe distances between a painted wood panel and the inner face of an exterior wall
}

\author{
Santi Ferrer ${ }^{1}$, Gema Campo-Francés ${ }^{2}$, Cristina Ruiz-Recasens ${ }^{2^{*}}$ and Marta Oriola-Folch ${ }^{2}$
}

\begin{abstract}
This study provides a detailed understanding of the heat fluxes and temperatures that take place in the channel between the inner face of an exterior wall and the back of a painted wood panel hung on it. This is performed by means of a numerical simulation with a 2 dimensional CFD software. Distributions of temperatures, heat fluxes, and other parameters are quantified for 56 cases where the classical equations-Raithby-Hollands and similar_cannot be applied as these require vertical isothermal plates or isofluxes. Studied scenarios include different panel heights, channe/ widths, and room heights. Combining these data with outside temperature $\left(-3^{\circ} \mathrm{C}\right)$ and heating air supply temperature $\left(20^{\circ} \mathrm{C}\right)$, to provide a nearly constant $19.6^{\circ} \mathrm{C}$ in the room except in the channel between panel and wall, and with two values of specific humidity in the room, we provide for every studied case, advised distances, for these conditions, between the panel and the wall.
\end{abstract}

Keywords: Museum microclimates, CFD model, Numerical simulation, Wall condensation, Easel painting condensation, Thermal convection

\section{Introduction}

If we place an easel painting or a painted wood panel in the interior face of an exterior wall (either touching the wall or very close to it) both act as thermal insulators. So, in historical buildings with non-thermally insulated exterior walls and low outside temperatures, the inside wall face and the painting back temperatures can drop some degrees below the room temperature and consequently the relative humidity $(\mathrm{RH})$ in these places can rise to unacceptable levels for the proper conservation of paintings [1]. Neuhaus [2] states that in this case, spacers shall be placed between paintings and wall in order to provide insulation at the painting back but required distances are not provided.

\footnotetext{
*Correspondence: cruiz@ub.edu

${ }^{2}$ Arts and Conservation Department, Fine Arts Faculty, University

of Barcelona, C/Pau Gargallo 4, 08028 Barcelona, Spain

Full list of author information is available at the end of the article
}

In Padfield previous study [3] temperature and $\mathrm{RH}$ have been measured on site and a minimum distance of $20 \mathrm{~mm}$ has been recommended between a $35 \mathrm{~cm}$ high framed painting and the inner face of a window facing north. Although broader distances have been suggested for bigger artefacts, specific values have not been calculated for this or other scenarios.

The aim of this research is not to set the exhibition room climatic conditions in historical buildings, which today in Europe are established by the CEN recommendations but to calculate the temperatures and heat flux distributions in the channel between a cold exterior wall and painted wood panels of different sizes placed at varying distances from the wall and at two different relative humidity values, to extend the general recommendation given in the Padfield study. Performing measurements on site requires large number of tests in different and very accurate environment conditions. The differential
Springer Open

(c) The Author(s) 2020. This article is licensed under a Creative Commons Attribution 4.0 International License, which permits use, sharing, adaptation, distribution and reproduction in any medium or format, as long as you give appropriate credit to the original author(s) and the source, provide a link to the Creative Commons licence, and indicate if changes were made. The images or other third party material in this article are included in the article's Creative Commons licence, unless indicated otherwise in a credit line to the material. If material is not included in the article's Creative Commons licence and your intended use is not permitted by statutory regulation or exceeds the permitted use, you will need to obtain permission directly from the copyright holder. To view a copy of this licence, visit http://creativeco mmons.org/licenses/by/4.0/. The Creative Commons Public Domain Dedication waiver (http://creativecommons.org/publicdomain/ zero/1.0/) applies to the data made available in this article, unless otherwise stated in a credit line to the data. 
equations that model heat transfer in fluids take into account three fundamental laws as the mass, momentum and energy conservation, and thus theoretically, they can solve the heat transfer simulation between the fluid and the boundaries in whatever complex geometry. However, as they are in not linear partial derivatives, they can be solved analytically only in a few particular cases through dimensional analysis and simplifications.

Heat transfer between two parallel vertical isothermal and isoflux plates through the air by natural convection has been well parametrized by Raithby-Hollands [4], Bar-Cohen [5], Cadafalch-Oliva [6], Spalding [7, 8], and others, but as the exterior wall and the wood panel are neither isothermal and nor isoflux plates, their equations cannot be applied.

Instead, at present, CFD tools offer the possibility to solve numerically differential equations that model heat transfer in our selected geometry and materials with enough accuracy and at a reasonable cost. The commercial 2D fluid mechanics software EasyCFD_G developed and tested by A. Gameiro of the Coimbra University [9-14], is used in this research to extend the only existing single recommendation, up to now, of minimum $20 \mathrm{~mm}$ for the distance between a "cold" external wall in historical buildings and a painting hung on it.

This tool allows us to use the $(k-\omega)$ or the $(k-\varepsilon)$ equations, where $k$ is for turbulent kinetic energy, $\varepsilon$ for its dissipation rate, $\omega$ for the turbulent kinetic energy frequency of dissipation, according to the distance from each mesh element to the boundaries and to quantify some magnitudes, raised in the Grau-Bové and Strlic article [15] such as the turbulence and the thermal fluxes in each mesh element, distinguishing between the contributions by convection and conduction.

These simulations show important vertical temperature gradients at the wall and the wood panel back when the room heating air supply $\left(20^{\circ} \mathrm{C}\right)$ provides a nearly constant value $\left(19.6{ }^{\circ} \mathrm{C} \pm 0.3 \mathrm{~K}\right)$ around the room (except in corners and in the space between the back of the panel and the wall).

The specific humidity (SH) is considered constant in all the room. The possible water buffer action from the boundary surfaces (walls and panel) is not considered, as the simulations are done for a steady state and this allows to simplify the problem and to get an easier understanding of the heat fluxes involved. Two SH scenarios are considered $(7.5 \mathrm{~g} / \mathrm{kg}$ and $8.7 \mathrm{~g} / \mathrm{kg})$ which correspond to $52 \%$ $\mathrm{RH}$ and $60 \% \mathrm{RH}$ both at $19.6{ }^{\circ} \mathrm{C}$.

From this point on, Wall refers to the inner face of the exterior wall, Back to the wood panel surface facing the channel and Front to the wood panel surface facing the room. Also the space between the inner side of the exterior wall and the back of the panel is named channel.

\section{Materials and methods}

\section{Simulation description}

We have built 8 different 2-dimensional CFD "models", each of them composed by a vertical cross-section of a room $3 \mathrm{~m}$ wide with a $2 \mathrm{~cm}$ thick wood panel hanging at different distances (" $s$ ") from the Wall. From this point on, the word panel will be used with the same meaning as wood panel.

All the models also have the same following features: heating system by hot air forced convection, distance from the panel centre to the floor $(1.5 \mathrm{~m})$ and boundary conditions. The difference among the 8 models lies in the following variables: different panel height " $h$ " $(2 \mathrm{~m}, 1 \mathrm{~m}$ and $0.5 \mathrm{~m}$ ), different room height " $h t$ " ( $3 \mathrm{~m}$ and $6 \mathrm{~m})$ to quantify the effect of the distance travelled by the air along the cooled inner face of the Wall before entering in the channel, one model without the panel (for comparison) and another model in a room $6 \mathrm{~m}$ high with a cornice $15 \mathrm{~cm}$ high and $5 \mathrm{~cm}$ wide protruding from the inner side of the outside wall at $30 \mathrm{~cm}$ above the wood panel.

For each of the 8 described models, there are different "cases" (one for each distance " $s$ " from panel to wall), see Table 1. Combining all the mentioned variables, we get 45 basic cases. All basic cases and models are listed in Table 1. See sketch in Fig. 1.

Doing it we have simulated 45 basic cases where in a heated room of different heights, painted wood panels of different dimensions (models) are hung at different short distances on the inner face of an exterior wall.

In these simulations we got air velocities $(u$ horizontal and $v$ vertical), temperatures ( $T w$ wall, $T b$ back and $T a$ air), heat fluxes and turbulence intensity $(T u)$ for each of

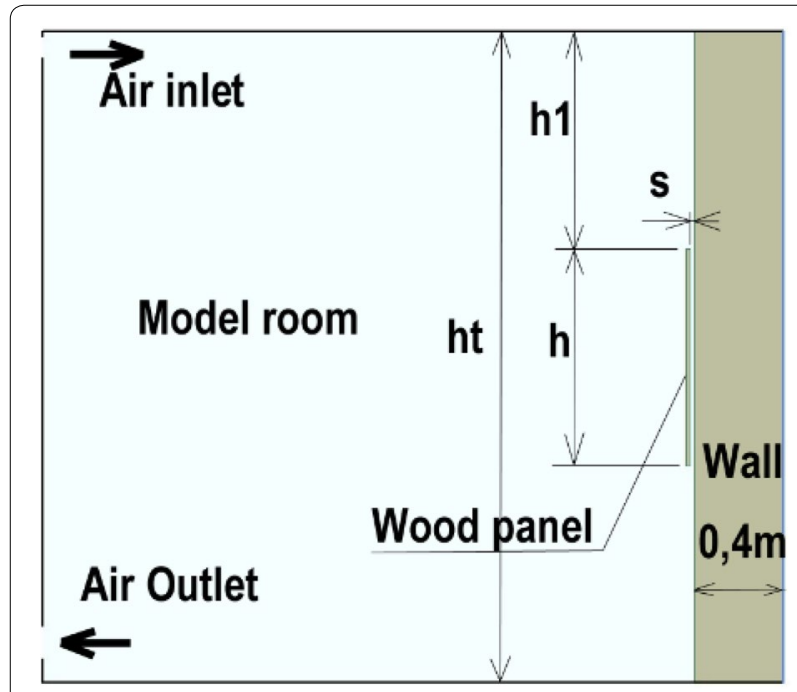

Fig. 1 Sketch room/panel case $12 \mathrm{ht}=3 \mathrm{~m}, \mathrm{~h}=1 \mathrm{~m}, \mathrm{~h} 1=1 \mathrm{~m}$, $\mathrm{s}=20 \mathrm{~mm}$ 


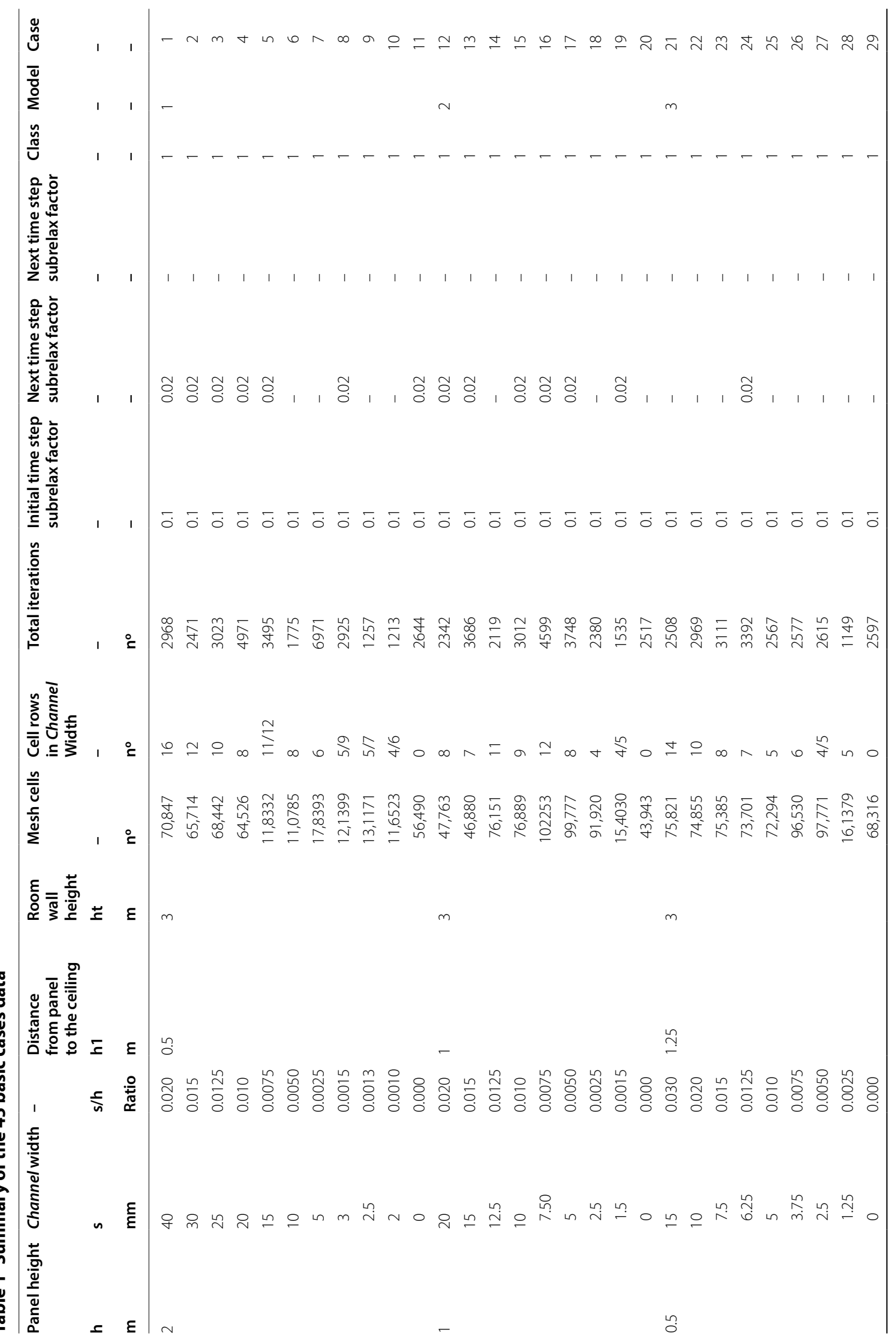




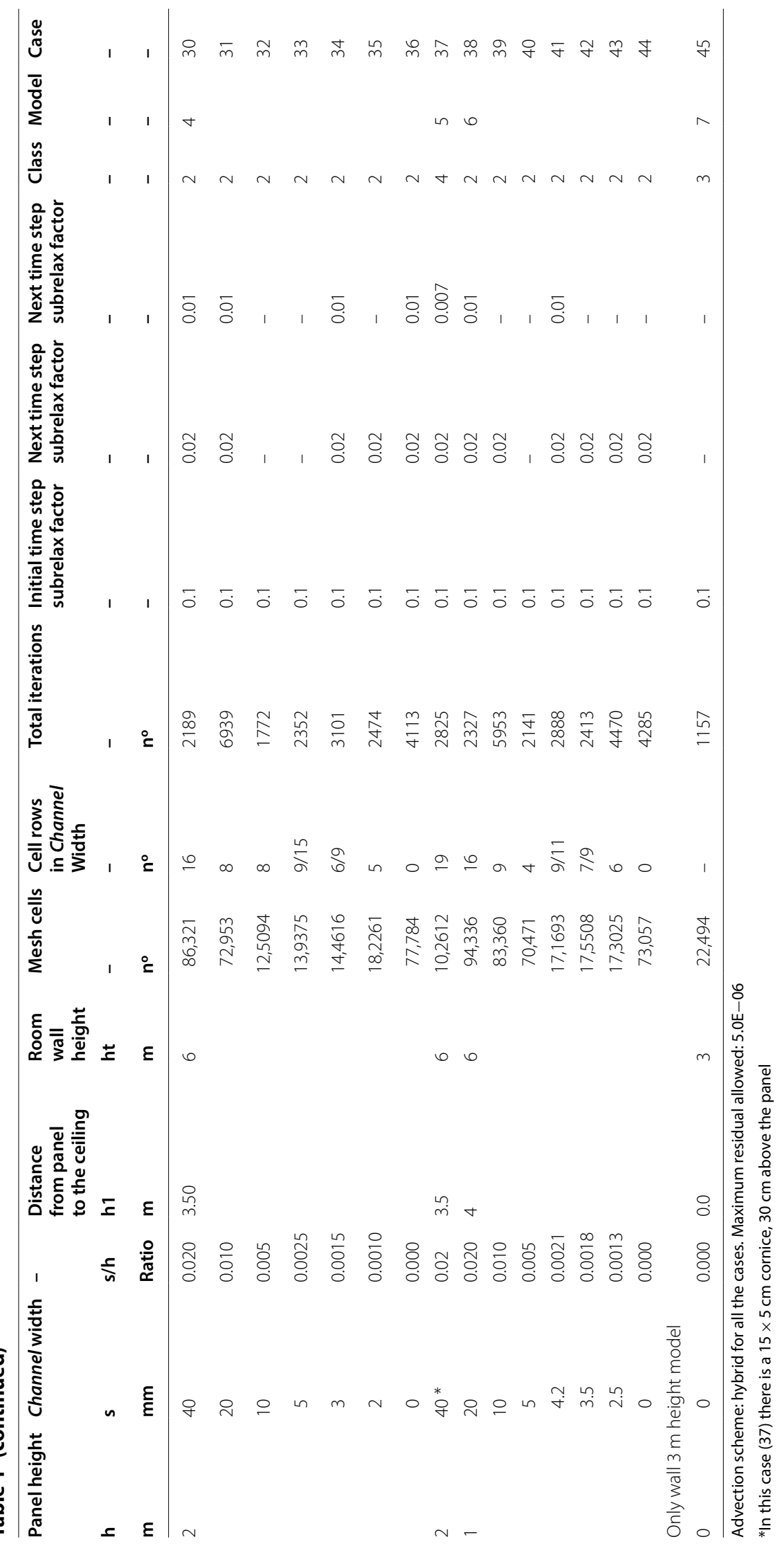


all the CFD mesh elements in the room (between 43943 and 182261). Thus, we have exported the temperatures and heat fluxes distribution from 100 points located in three vertical layers along the panel height: along the Back, along the Front and along the Wall. Knowing these temperatures distribution and the $\mathrm{SH}$ in the room, we have calculated the RH values in these same 100 points for the two SH scenarios.

Besides, we also got the air velocities and turbulence intensity along the channel that helps to improve the understanding of the heat and mass transfer through the channel. Comparing the exported values, we have seen that in addition to the classical non-dimensional number $s / h$ (channel width/wood panel height) there are other parameters (as the distances from the ceiling to the panel or the possibility of eddies at the channel inlet and outlet) that can modify the temperature and the heat flux distribution in the channel.

\section{Heat transfer parameters and room conditions Walls and wood panel heat conduction}

The room floor, the roof and the inner wall are adiabatic. The exterior wall is limestone $41 \mathrm{~cm}$ thick, and includes a $1 \mathrm{~cm}$ mortar layer. The exterior wall parameters are: thermal conductivity $k_{h}=1.8 \mathrm{~W} / \mathrm{m} \mathrm{K}$, density $\rho=2095 \mathrm{~kg} / \mathrm{m}^{3}$, and specific heat or fluid heat capacity $c p=903 \mathrm{~J} / \mathrm{kg} \mathrm{K}$, all including the correction factor for the mortar layer. The parameters used for the wood panel are: $k_{h}=0.2 \mathrm{~W} / \mathrm{m} \mathrm{K}$, $\rho=700 \mathrm{~kg} / \mathrm{m}^{3}$, and $c_{p}=1600 \mathrm{~J} / \mathrm{kg} \mathrm{K}$.

Although as stated in the Fourier equation $\rho c_{p} \frac{\partial T}{\partial t}=0$, with $T$ for temperature and $\mathrm{t}$ for time, the $\rho$ and $c_{p}$ values are not required for heat fluxes through solid materials in steady conditions (see Additional file 1: Appendix S2.1 point $D$ ), we use them in the calculations as they are required for the transient approach, with a virtual time factor, used to get a more stable convergence (see Additional file 1: Appendix S2.2) As in this study we are not concerned with the real time needed to reach the steady condition, the temperature and heat flux obtained are applicable to other exterior walls and hung panels provided with correlated conductivity materials and widths (same width $* k_{h}$ ).

Outdoor air temperature set for all the simulations is $-3{ }^{\circ} \mathrm{C}$ and outdoor heat convection boundary film coefficient has been considered to be $25 \mathrm{~W} / \mathrm{m}^{2} \mathrm{~K}$ as recommended for building heat load calculations under normal wind conditions.

\section{Heating by air convection}

In order to maintain temperature in the room at $19.6{ }^{\circ} \mathrm{C} \pm 0.3 \mathrm{~K}$ (except for the four corners and a narrow area near the exterior wall and the floor) we have simulated a forced convection system blowing air into the room at $20^{\circ} \mathrm{C}$ and at $1 \mathrm{~m} / \mathrm{s}$ for a room $3 \mathrm{~m}$ high. In this 2D simulation, the air enters the room through a grille $0.1 \mathrm{~m}$ high, located on the upper corner of the opposite wall from the wood panel. The air direction is shifted by the grille $-15{ }^{\circ} \mathrm{C}$ from the horizontal axis to counteract part of the Coanda effect. The air is exhausted by an identical grille near the floor level in conservative conditions. Done this way, we achieve a very homogeneous temperature distribution without stratification.

Air supplied in models with rooms $6 \mathrm{~m}$ high is blown at $2 \mathrm{~m} / \mathrm{s}$ and $20{ }^{\circ} \mathrm{C}$ (instead of $1 \mathrm{~m} / \mathrm{s}$ ) to compensate heat losses through the exterior wall which is twice the area of the wall $3 \mathrm{~m}$ high and to achieve the $19.6{ }^{\circ} \mathrm{C} \pm 0.3 \mathrm{~K}$ in the room.

Inside the room the air conduction heat coefficient used in the boundary layer laminar flow is $0.0255 \mathrm{~W} / \mathrm{m} \mathrm{K}$.

\section{SH scenarios}

Two different $\mathrm{SH}$ scenarios, both within the range of proper museum conditions, have been set out to calculate the RH values in the different areas of the room, according to the temperatures computed in the CFD models and cases. In this way the channel microclimate was correctly quantified. The conditions for both scenarios are the following:

Scenario SH1: $52 \% \mathrm{RH}$ in a room heated at $19.6{ }^{\circ} \mathrm{C}$ with a Dew Point of $9.7^{\circ} \mathrm{C}$ and a $\mathrm{SH}=7.5 \mathrm{~g}$ water $/ \mathrm{kg}$ air, which corresponds to high occupation $\left(5 \mathrm{~m}^{2} /\right.$ person $)+$ natural infiltration at 1 Volume/h with outside air at $-3{ }^{\circ} \mathrm{C}$ and $90 \% \mathrm{RH}$.

Scenario SH2: $60 \% \mathrm{RH}$ in a room heated at $19.6{ }^{\circ} \mathrm{C}$ with a Dew Point of $11.9^{\circ} \mathrm{C}$ and a $\mathrm{SH}=8.7 \mathrm{~g}$ water $/ \mathrm{kg}$ air, which corresponds to middle occupation $\left(8 \mathrm{~m}^{2} /\right.$ person) + natural infiltration at 0.5 Volumes/h with outside air at $-3{ }^{\circ} \mathrm{C}$ and $90 \% \mathrm{RH}$.

\section{$\mathrm{RH}$ criteria for the proper conservation of the artistic assets}

To guarantee the proper conservation of the artistic assets, the following two criteria have been set: 1) $\mathrm{RH}$ in the panel Back must be $<66 \%$; 2) If $\mathrm{RH}$ in the Wall $=100 \%$, at least " $s " \geq 2 \mathrm{~cm}$.

The first criterion corresponds to the Smithsonian Institution standard for $\mathrm{RH}$ in exhibition rooms released in 2007 [16] which established the range from $37 \%$ to $53 \%$ and was extended by Erhardt et al. [17] to $30 \%<\mathrm{RH}<60 \%$ after the tests performed on different art materials such as wood, pigments, paint layers, gesso, etc. Also the present ASHRAE conditions $[16,18,19]$ can be met with two options for class A (this class foresees small risk of mechanical damage to high vulnerability artifacts and no mechanical risk to most artifacts, paintings, photographs, and books). The first one is RH from 35 to $65 \%$ with the set point at $50 \%$, allowing $\pm 10 \%$ seasonal set 
point variations and $\pm 5 \%$ short term fluctuations. This option allows to extend the $\mathrm{RH}$ up to $65 \%$. The second one is $\mathrm{RH}$ within the range of $40-60 \%$ with $50 \%$ as a permanent set point for the whole year and $\pm 10 \%$ short term fluctuations.

Our second criterion-a minimum separation of $2 \mathrm{~cm}$ between the panel Back and the Wall when this later is at $100 \% \mathrm{RH}-$ is under review and it is considered only as a temporary solution in the case that it is impossible to change the painting location or to improve the exterior wall isolation, as it usually happens in some historical buildings.

Actually others standards as EN 15757 [20], EN15759-1 [21] and EN 15759-2 [22] are developed to deal with climate at historical buildings, churches and chapels where wood panels and easel paintings have been submitted to important $\mathrm{RH}$ variations along the centuries and have been adapted to the climate conditions showing visible effects such as cracks and flakes or not visible as plastic strains. In these cases, changing the historical climate conditions for others theoretically better may lead to a more endangered condition of the weak artwork.

These standards allow the seasonal $\mathrm{RH}$ set point to move in a broader range (safe band), according to the computed mean average (CMA) calculated after 13 months of measured $\mathrm{RH}$ inside values and the conservators criteria about the exposed or stored artwork condition, as Camuffo [23, 24], Bratasz [25, 26], Broström et al. [27], Neuhaus and Schellen [28], Schijndel [29] and others have explained.

Today the room RH control in exhibitions and museums varies according to the institutions economic saving policy and energetic goals, the condition and history of exposed or stored objects, the wall materials and air tightness, the importance of the visitors comfort, and other factors.

In order to simplify, in our research we have used, as $\mathrm{RH}$ threshold, the maximum allowed value in the ASHRAE standard for the A class. It was not possible to give a universal solution to all the real cases, as this involves studying the endless combinations of temperature and $\mathrm{RH}$ possible conditions, the different isolation and thermal inertia of the walls, the unlike building shapes, the varying $\mathrm{RH}$ buffers, etc. Our goal is to improve the understanding of heat fluxes, $\mathrm{RH}$ and temperatures that take place at the back of wood paintings on exhibition hung in peripheral walls in order to provide conservators with the knowledge to be applied in cases with similar conditions.

\section{Complementary cases}

After the analysis of the 45 basic cases, only 3 of them complied the RH values to avoid damages in the artistic asset. Thus, we have extended the simulations to other complementary cases and by a trial and error procedure we have found the distances required, from the panel to the Wall, to comply with the required $\mathrm{RH}$ in each layer. In this way we got 9 complementary cases, all of them in the same conditions as before, but not exceeding the $66 \%$ $\mathrm{RH}$ in both $\mathrm{SH}$ scenarios. In the cases of water condensation in the Wall a minimum of $20 \mathrm{~mm}$ from Back to Wall is maintained. Also we have extended the simulations to 2 complementary cases by adding $60 \mathrm{~mm}$ of expanded polystyrene (EPS) insulation to the exterior wall and to 2 other complementary cases (channel width $8 \mathrm{~mm}$ and $20 \mathrm{~mm}$ ) adding an aluminium protection layer, $0.5 \mathrm{~mm}$ thick, at the Back which improves greatly the Back temperatures. As the $8 \mathrm{~mm}$ channel width case has a minimum Wall temperature of $7.3^{\circ} \mathrm{C}(\mathrm{RH}=100 \%)$ we cannot recommend it and the $20 \mathrm{~mm}$ minimum channel width is recommended for the Wood panel with Aluminium protection. For the isolated wall composition see Table 2.

Like this, we have extended the general recommendation [3] that states a minimum of $20 \mathrm{~mm}$ between a painting and an exterior wall, to more detailed specifications according the different situations. In addition we quantified and clarified the heat transfer modes between the Back and the Wall in these circumstances.

There are other possible variables to take in account, as possible different panel thickness, obstacles to the air flow as cradling, other room or outside temperatures, other inside $\mathrm{SH}$, other geometries, etc., but we have focused in our variables in order to understand and quantify the temperatures, $\mathrm{RH}$ and heat fluxes in different conditions, to provide to the conservators the knowledge to understand and deal with the particular conditions they would find.

\section{Calculation procedure. Equations used}

The equations used are the conservation of mass (continuity) equation, the conservation of momentum (Navier-Stockes) equations, the conservation of energy (transport equation for enthalpy) equation and the heat transfer through solids (wall and wood panel) equation which it is the Fourier equation but without internal heat production.

\begin{tabular}{|c|c|c|c|}
\hline \multirow[t]{2}{*}{ Material } & \multirow[t]{2}{*}{ Layer } & \multirow{2}{*}{$\begin{array}{l}\text { Width } \\
\mathrm{cm}\end{array}$} & \multirow{2}{*}{$\begin{array}{l}\text { Thermal } \\
\text { conductivity } \\
\mathrm{W} / \mathrm{m} \mathrm{K}\end{array}$} \\
\hline & & & \\
\hline Concrete block & Outside & 25 & 1 \\
\hline EPS insulant & Internal & 6 & 0.038 \\
\hline Ceramic brick & Inside & 10 & 0.6 \\
\hline
\end{tabular}




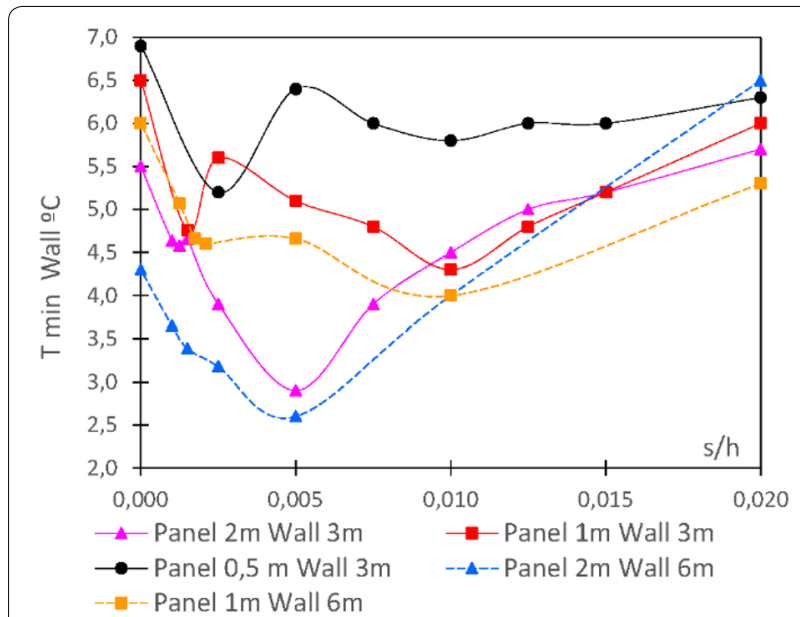

Fig. 2 Wall minimum temperature (basic cases)

All these equations are developed in Additional file 1: Appendix S2.1

The procedure used to solve these equations in a steady flow is shown in Additional file 1: Appendix S2.2

The boundary and initial conditions used to solve these equations are shown in Additional file 1: Appendix S2.3

\section{Results}

Temperature and heat flux values in 100 points of the CFD simulation, distributed in the vertical axis along the interface layers-Wall/channel air, channel air/Back, and Front/room air-have been exported for each case.

Also for each of the cases, the temperature and the vertical component (v) of the air velocities have been exported from 20 points distributed horizontally along the channel inlet between the Wall and the panel to compute $T i$, the channel inlet air mean temperature (vertical velocity weighed).

For the cases of the model where the wood panel is $50 \mathrm{~cm}$ high, the turbulence intensity (Tu) has also been exported in order to compute the turbulence intensity average (Turb) at different heights along the channel. Doing it in this way, the computed heat fluxes have been assigned to the different convection modes (laminar or turbulent) in the detailed analysis of "Heat fluxes and minimum temperatures in the Wall and the Panel Back" section.

In Figs. 2 and 3 the minimum temperatures in the Wall and the Back can be seen for all models and cases.

Figures 4, 5 and 6 show the averaged heat fluxes for all models and cases. Figure 4 displays the total heat flux received by the Wall, Fig. 5 the heat flux supplied by the Back and Fig. 6 the heat flux supplied directly by the air entering the channel. Figure 7 shows heat flux ratios

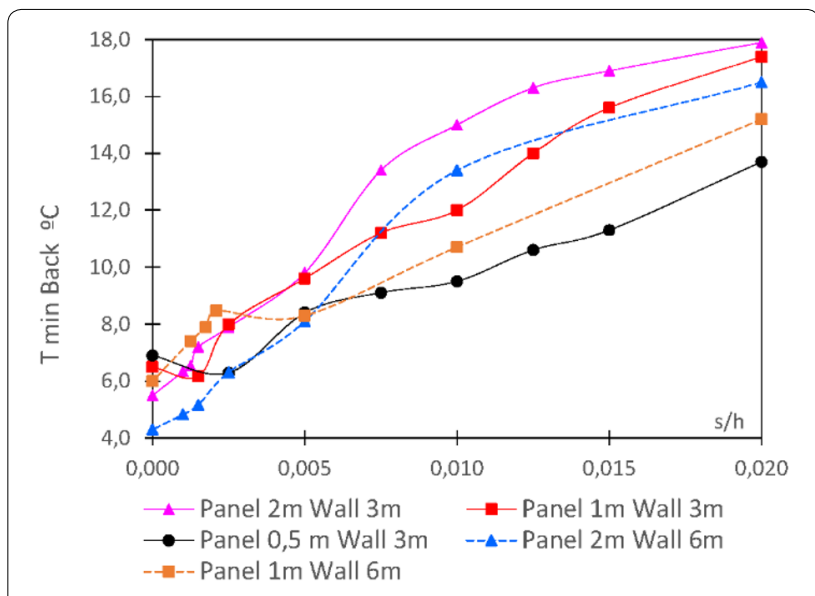

Fig. 3 Minimum back temperature (basic cases)

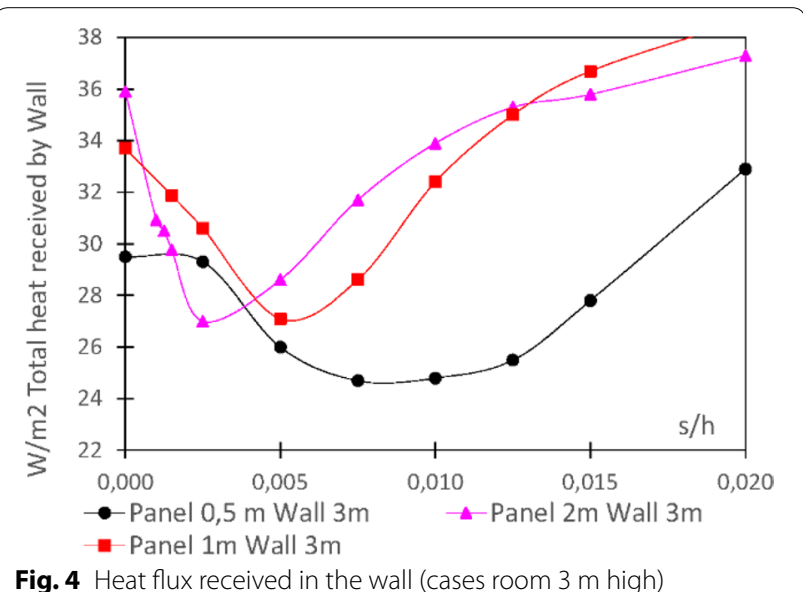

Fig. 4 Heat flux received in the wall (cases room 3 m high)

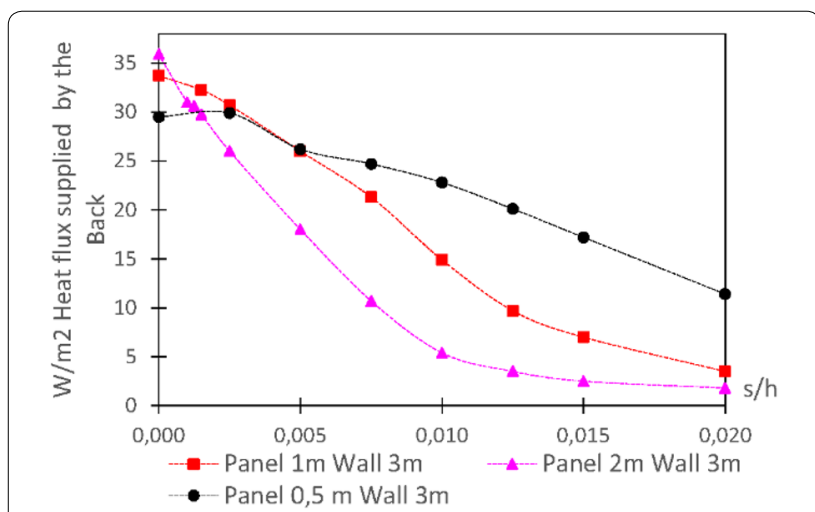

Fig. 5 Heat flux supplied by back (cases room 3 m high) 


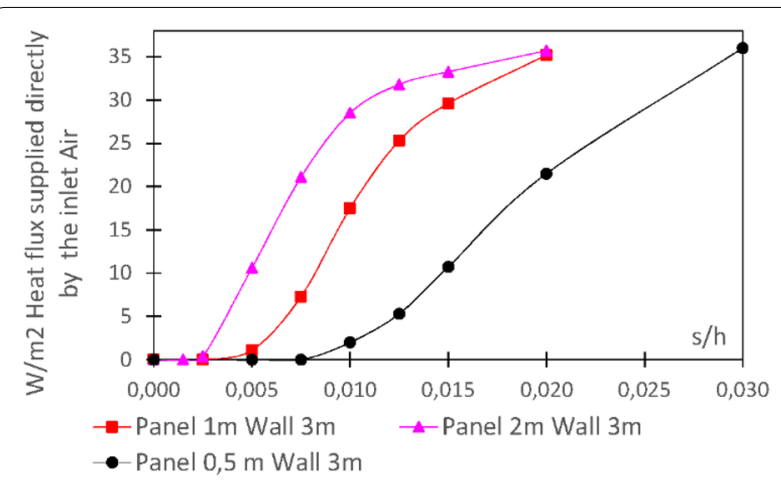

Fig. 6 Heat flux supplied by inlet air (cases room 3 m high)

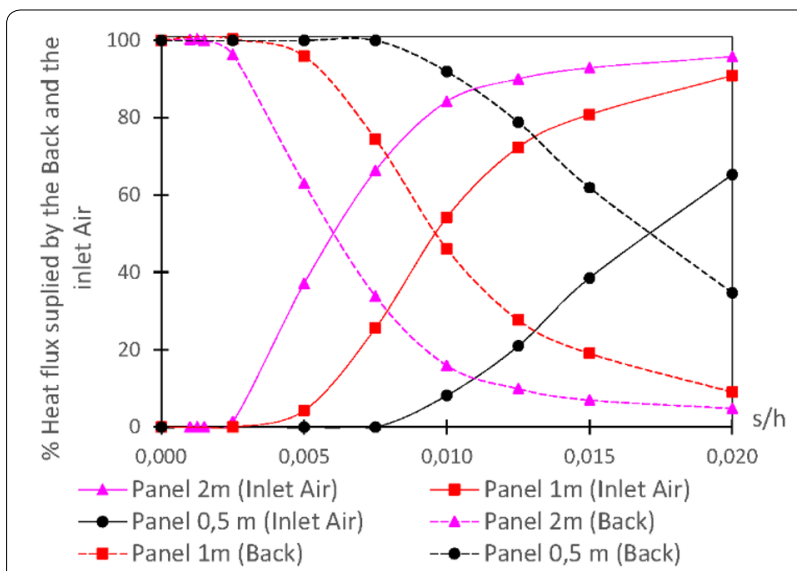

Fig. 7 Heat flux back and inlet air \% (cases room 3 m high)

between Back and Wall (total) and also between Inlet air and Wall (total). In all these graphics heat fluxes and temperatures are plotted versus the "s/h" adimensional number.

Table 3 presents all these values for the 45 main cases together with other parameters such as dimensions, plus the inlet air eddy, if it appears. In addition, RH in the Wall, the Back and the Front are included for the scenarios $\mathrm{SH} 1$ and $\mathrm{SH} 2$.

For complementary information, see Additional file 1: Table S0.1 in Additional file 1: Appendix S0 with more detailed results for each layer (Wall, Back and Front).

\section{Discussion}

\section{Heat fluxes and minimum temperatures in the Wall} and the Panel Back

In Additional file 1: Appendix S1 there is a detailed analysis of the heat fluxes, turbulence and temperatures at different heights in the channel between Back and Wall for all the cases in a $50 \mathrm{~cm}$ high panel. It allows to understand the involved phenomena and temperatures distributions in the channel.
We can see how the Wall temperature decreases as the panel separates from the Wall, due to the laminar flow close to the Wall, and thus the heat flux is only by conduction. Added to the effects of the eddy locations in the channel inlet and channel outlet, the temperature attain a minimum at $s=1.25 \mathrm{~mm}$. As the channel width continues increasing at $s=2.5 \mathrm{~mm}$ the outlet eddy change its direction and the Wall is heated enough to compensate the conduction heat flow reduction and the Wall temperature attain a relative maximum.

As the channel width continues increasing at $s=5 \mathrm{~mm}$, it appears another temperature minimum. If the channel width continues increasing and attain $s=7.5 \mathrm{~mm}$, the heat flux to the Wall increases, as inlet air heat flux increases more than the Back heat flux decreases (due to the increasing of inlet air flow and turbulence). This raises the Wall temperatures.

From this point the Back and Wall temperatures increase, approaching the air room temperatures. It is quantified in Additional file 1: Table S1.1 and explained with detail in Additional file 1: Appendix S1.

Figure 2 and Table 3 show how the two Wall temperature minimums discussed in Additional file 1: Appendix S1 for a $50 \mathrm{~cm}$ high panel also appear for panels with $h=1 \mathrm{~m}\left(4.8{ }^{\circ} \mathrm{C}\right.$ and $\left.4.3^{\circ} \mathrm{C}\right)$ and for panels with $h=2 \mathrm{~m}$ $\left(4.58{ }^{\circ} \mathrm{C}\right.$ and $\left.2.9^{\circ} \mathrm{C}\right)$ in a room $3 \mathrm{~m}$ high and for panel with $h=1 \mathrm{~m}\left(4{ }^{\circ} \mathrm{C}\right.$ and $\left.4.6{ }^{\circ} \mathrm{C}\right)$ in a room $6 \mathrm{~m}$ high. As $h 1$ (distance from the panel upper border to the ceiling) increases, the difference between the first minimum Wall temperature and the intermediate maximum decreases. The intermediate maximum nearly disappears for $h=2 \mathrm{~m}$ and $h 1=3 \mathrm{~m}$. As $h$ increases, the second minimum is displaced to lower $s / h$ values (to the left side of the curve in Fig. 2).

The explanation is that as $h 1$ increases, more cooled is the air descending close to the Wall and the Ti (average air inlet channel temperature) is lower. Thus, the air layer cooled by the Wall is wider and more air mass is cooled. This can be seen in the Table 3, column $T_{i}$ (Channel inlet air mean temperature, vertical velocity weighed).

However, the phenomenon is not that simple and other factors shall also be considered.

\section{The air mass flow going into the channel}

It can be seen in the special case for $h=2 \mathrm{~m}, s=40 \mathrm{~mm}$, where the minimum Wall temperature for $h t=6 \mathrm{~m}$, is higher $\left(6.5^{\circ} \mathrm{C}\right)$ than for $h t=3 \mathrm{~m}\left(5.7^{\circ} \mathrm{C}\right)$. For $h t=6 \mathrm{~m}$, the air mean velocity in the channel inlet is $0.6 \mathrm{~m} / \mathrm{s}$ (at $16.4{ }^{\circ} \mathrm{C}$ as average) whereas for $h t=3 \mathrm{~m}$ it is $0.3 \mathrm{~m} / \mathrm{s}$ (at $18{ }^{\circ} \mathrm{C}$ average). Thus, being the air mass twice for $h t=6 \mathrm{~m}$ and the air temperature only $1.6 \mathrm{~K}$ lower, the inlet air thermal energy level is higher for $h t=6 \mathrm{~m}$ than for $h t=3 \mathrm{~m}$ and it provides enough heat to raise the minimum Wall 


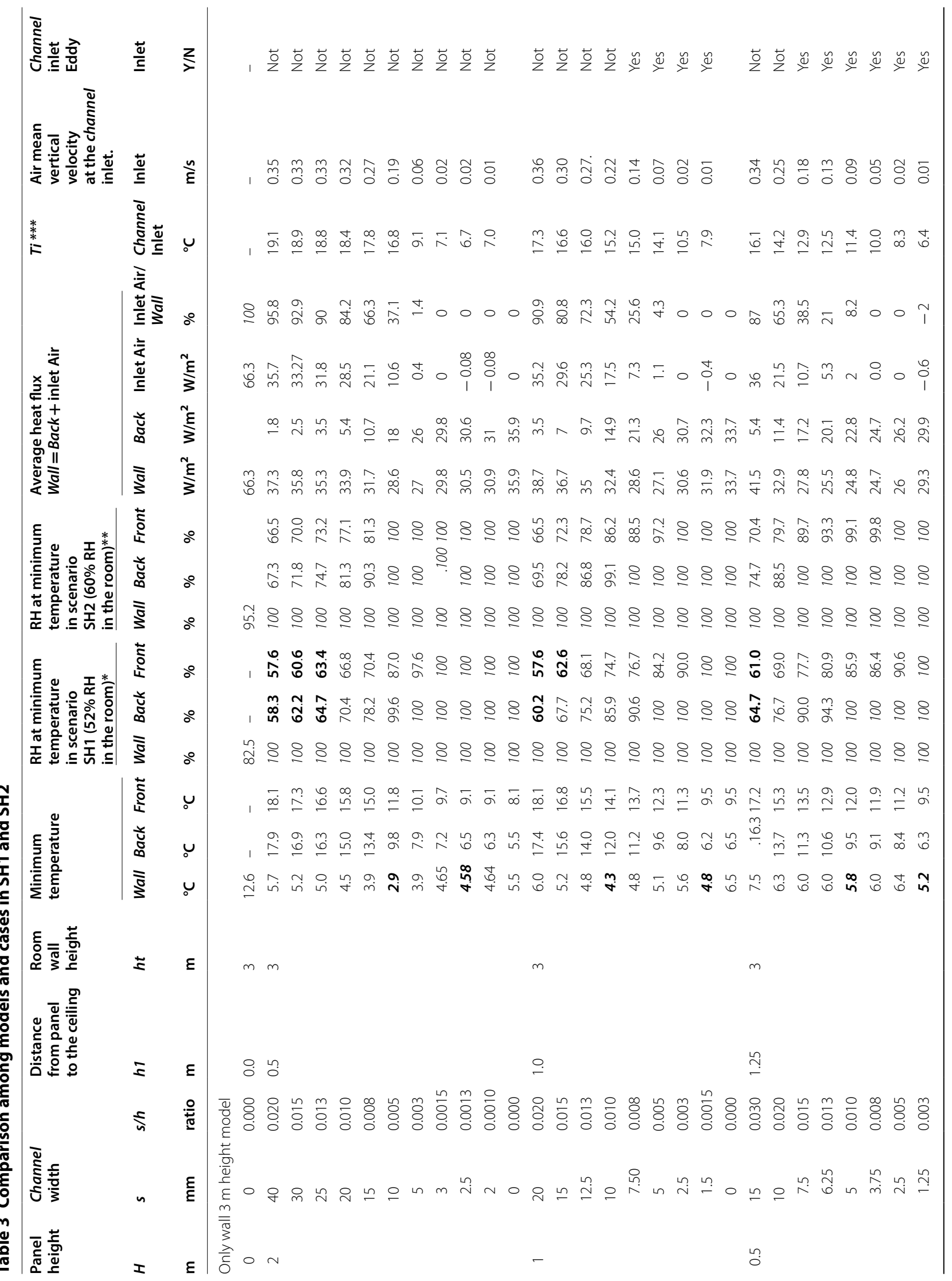




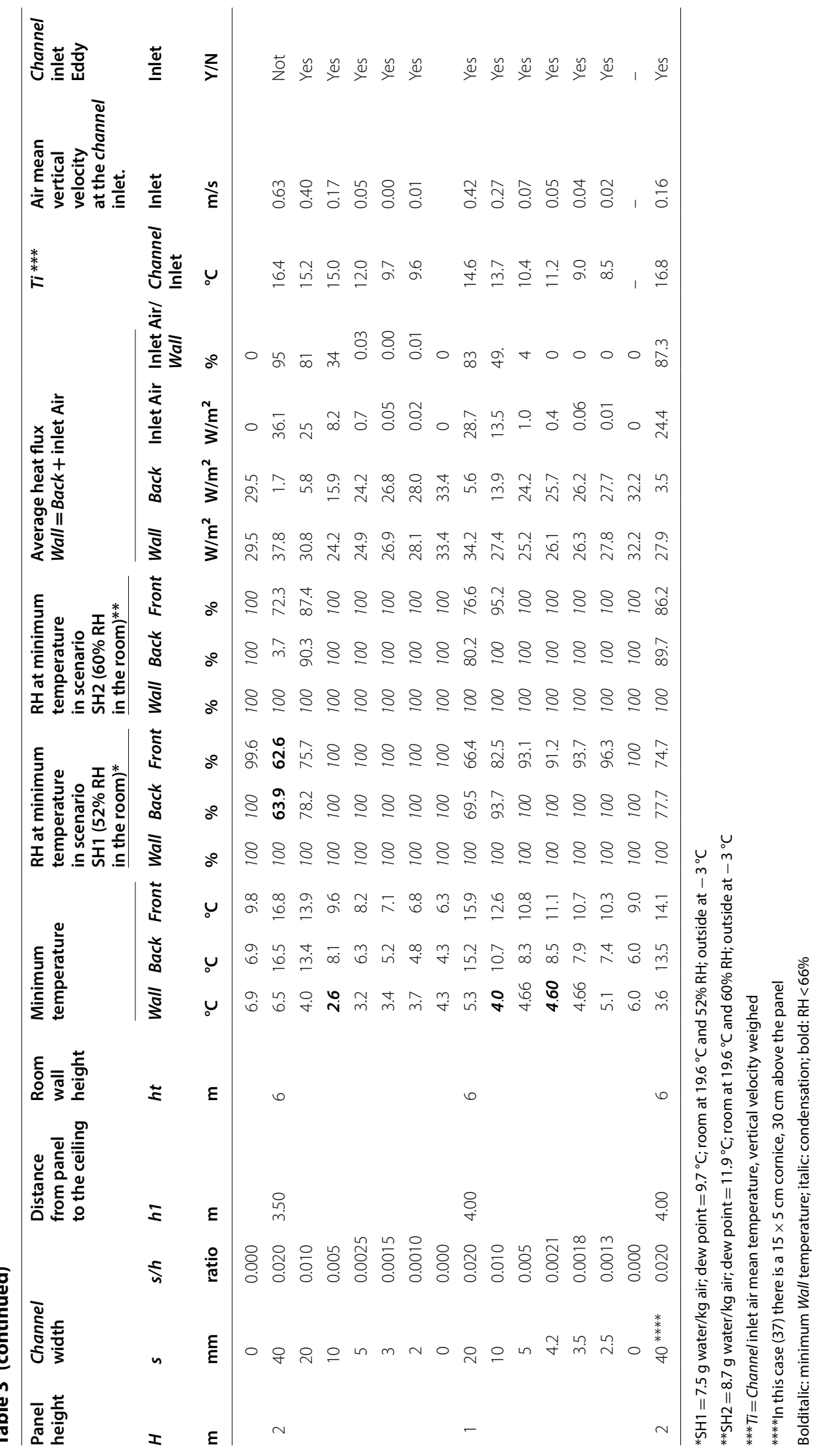


temperature up to $6.5{ }^{\circ} \mathrm{C}$. When " $\mathrm{s}$ " diminishes, as in the case of $h=2 \mathrm{~m}$ and $s=20 \mathrm{~mm}$, the minimum Wall temperature is $4{ }^{\circ} \mathrm{C}$ for $h t=6 \mathrm{~m}$ (inlet velocity $0.4 \mathrm{~m} / \mathrm{s}$ at $15.2{ }^{\circ} \mathrm{C}$ ) and $4.5{ }^{\circ} \mathrm{C}$ for $h t=3 \mathrm{~m}$ (inlet velocity $0.32 \mathrm{~m} / \mathrm{s}$ at $18.4{ }^{\circ} \mathrm{C}$ ). In this case, the air velocities are closer and the inlet air thermal energy level is lower for $h t=6 \mathrm{~m}$ than for $h t=3 \mathrm{~m}$. An intermediate case is for $h=2 \mathrm{~m}, s=30 \mathrm{~mm}$ where the minimum Wall temperatures are the same for $h t=6 \mathrm{~m}$ and for $h t=3 \mathrm{~m}\left(5.2^{\circ} \mathrm{C}\right)$.

\section{The air turbulence in the channel}

For small values of " $s$ " (channel width), the air flux is laminar and the heat transfer from the Back is only by conduction. This heat flux diminishes lineally as " $s$ " increases, but as " $s$ " increases more inlet air goes into the channel and the inlet air becomes the heat flux mean supplier to the Wall. As the channel air flow increases the heat flux turns to be turbulent and the addition of the both effects results in the curve " $s / h$ " versus heat flux with a minimum in the zone where the inlet air heat flux starts ( $s / h$ between 0.003 and 0.01 ). This phenomenon can be observed in the three curves of Fig. 4 which are, in turn, composed by the curves of Figs. 5 and 6 . The minimum in these curves moves to the right side of the chart as the panel height decreases. In order to further clarify this, Fig. 7 gathers these curves expressed as a percentage.

Also, as shown in Additional file 1: Appendix S1, when the channel is very narrow, air turbulence decreases as the air goes down inside the channel. In these cases, the air flux becomes laminar, still if it has been turbulent just near the channel inlet.

Depending on Temperatures, " $s$ " and " $h$ " parameters, the minimum temperature occurs at mid-height or at the lower zone of the channel. (See Additional file 1: Appendix S0, Table S0.1).

\section{The eddy in the channel inlet}

The widening of the air layer descending close to the Wall due to large values of $h 1$ and the narrowing of the channel can form an air eddy in the channel inlet, as more mass of the cooled air descending close to the Wall collides with the top edge of the panel. In this way the air going down close to the Wall gets mixed with the air of the room that enters the channel. This smooths the temperature differences in the channel inlet between the Back and the Wall. The developed eddy is shown in Figs. 8, 9 and 10.

Table 3 shows in which cases an eddy is developed at the inlet.

\section{The eddy in the channel outlet}

Usually one or more air eddies appear in the channel outlet. Depending on the position of these eddies, heated air of the room around the outlet can get mixed with the cooled air of the channel. This may cause heating of the Wall just under the channel. For example, in the case of a panel $50 \mathrm{~cm}$ high and a channel width of $2.5 \mathrm{~mm}$ (case 27), the Wall under the panel is heated enough by the outlet eddy to send heat flux by conduction through the Wall in vertical direction, raising the minimum temperature in the Wall (see Fig. 11 for $\mathrm{s}=2.5 \mathrm{~mm}$ ). In this same case, this factor explains the maximum of $6.4{ }^{\circ} \mathrm{C}$ in the "Wall minimum temperature" compared to the two neighbouring minimums of $5.2{ }^{\circ} \mathrm{C}$ that occur when $s=1.25 \mathrm{~mm}$ where the eddy is too weak to heat the Wall enough and $5.8^{\circ} \mathrm{C}$ when $s=5 \mathrm{~mm}$ where the heated air of the room is not sent to the Wall near the channel outlet and, instead, the cooled channel air flows into the room (see Table 3 and Fig. 11 with $\mathrm{s}=5 \mathrm{~mm}$ ).
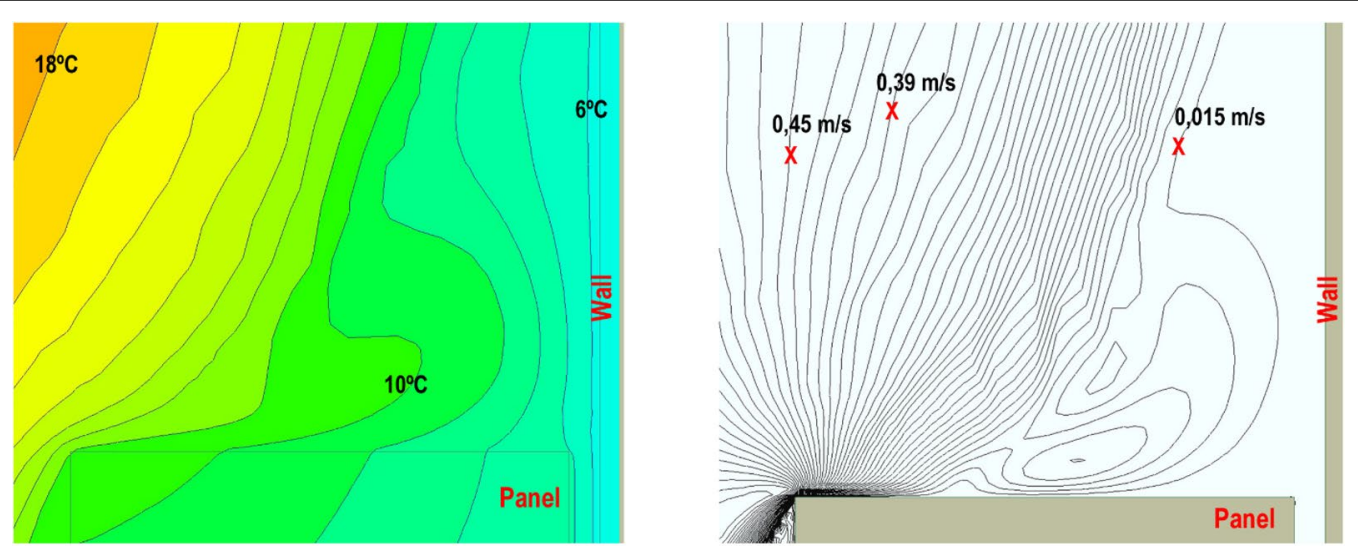

Fig. 8 Channel inlet temperature and velocity isolines. Case 28. Panel $h=50 \mathrm{~cm} . \mathrm{s}=1.25 \mathrm{~mm} . \mathrm{h} 1=1.25 \mathrm{~m}$. Values at inlet: $\mathrm{Tw}=5.7^{\circ} \mathrm{C}, \mathrm{Tb}=6.7^{\circ} \mathrm{C} . \mathrm{T}$ average $=6.4^{\circ} \mathrm{C}$. Air channel vertical mean velocity $=0.01 \mathrm{~m} / \mathrm{s} . \Delta \mathrm{v}$ between isolines $=0.015 \mathrm{~m} / \mathrm{s}$. Inlet eddy 

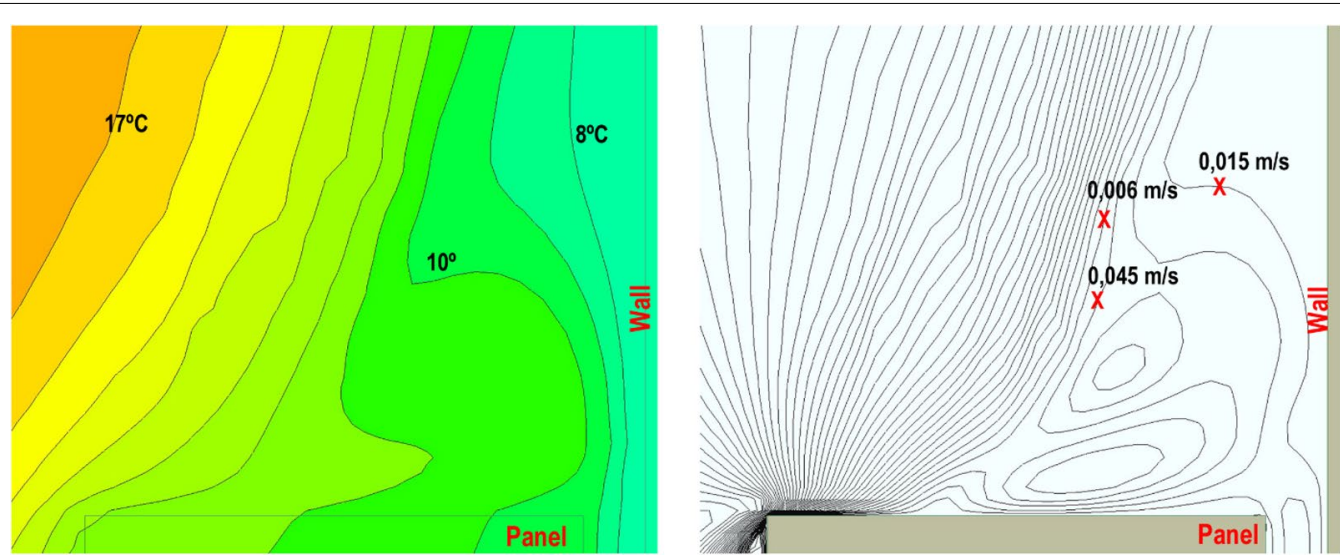

Fig. 9 Channel inlet temperature and velocity isolines. Case 27. Panel $h=50 \mathrm{~cm} . \mathrm{s}=2.5 \mathrm{~mm}$. $\mathrm{h} 1=1.25 \mathrm{~m}$. Values at inlet: Tw $=6.8{ }^{\circ} \mathrm{C}, \mathrm{Tb}=8.6^{\circ} \mathrm{C}$. T average $=8.3^{\circ} \mathrm{C}$. Air channel vertical mean velocity $=0.02 \mathrm{~m} / \mathrm{s} . \Delta$ v between isolines $=0.015 \mathrm{~m} / \mathrm{s}$. Inlet eddy
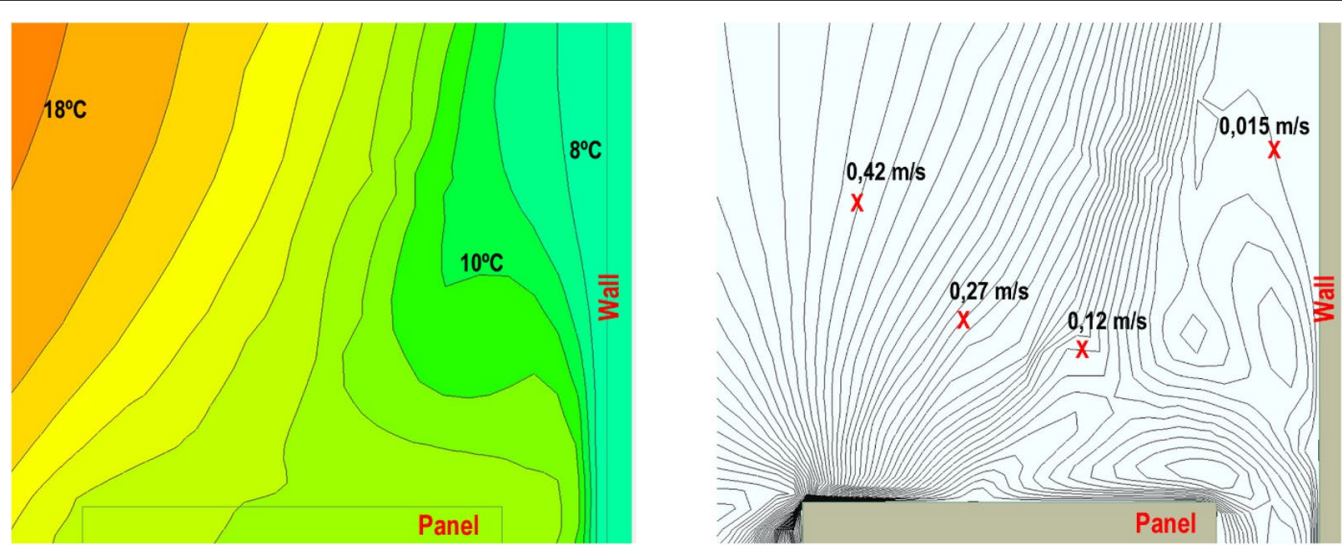

Fig. 10 Channel inlet temperature and velocity isolines. Case 25. Panel $h=50 \mathrm{~cm} . \mathrm{s}=5 \mathrm{~mm}$. $\mathrm{h} 1=1.25 \mathrm{~m}$. Values at inlet: Tw $=7.8^{\circ} \mathrm{C}, \mathrm{Tb}=11.2^{\circ} \mathrm{C} . \mathrm{T}$ average $=11.4^{\circ} \mathrm{C}$. Air channel vertical mean velocity $=0.09 \mathrm{~m} / \mathrm{s} . \Delta v$ between isolines $=0.015 \mathrm{~m} / \mathrm{s}$. Inlet eddy

\section{Cornices over the panel}

In the case of a cornice protruding from the Wall $(s=40 \mathrm{~mm}$, case 37$)$ it can be seen that the minimum temperatures in each layer are at least $3{ }^{\circ} \mathrm{C}$ lower that in the case with a straight Wall, due to the air flux deviation at the cornice and the eddy developed below it, that reduces the entrance of hot air from the room to the channel. So, the mean air temperature, vertical velocity weighed at the channel inlet, is reduced from 0.62 to $0.16 \mathrm{~m} / \mathrm{s}$ (compared to the same geometry without cornice as it is the case 1) and still if the mean air temperature at this point is increased from 16.4 to $16.8{ }^{\circ} \mathrm{C}$, the mean heat flux received by the Wall in the channel drops from 36.1 to $27.9 \mathrm{~W} / \mathrm{m}^{2}$ (see Table 3 ).

In order to compensate the Back and Wall temperature reduction and the heat flux reduction which occurs in this case, and to get the correct temperatures and $\mathrm{RH}$ values in the Back, it is necessary to increase the channel width from 40 to $90 \mathrm{~mm}$ in scenario SH1 and from 85 to $140 \mathrm{~mm}$ in scenario SH2 (see Tables 4 and 5).

\section{$\mathrm{RH}$ values in the different cases}

Table 3 also shows the maximum RH values of the significant layers (Wall, Back and Front) for scenarios SH1 and SH2. In both scenarios condensation appears on the Wall and, in many cases, $\mathrm{RH}$ values in the Back are above $66 \%$, which is the limit set for the proper conservation of paintings.

\section{Minimum required distances from a painted wood panel to the exterior wall}

From the results of the 3 basic cases, that comply with the two conservation criteria set in Sect. 2.3, and the 13 complementary cases, we got a set of 8 cases for the $\mathrm{SH} 1$ scenario (room $\mathrm{RH}$ of $52 \%$ at $19.6{ }^{\circ} \mathrm{C}$ ) and other set of 8 cases for the $\mathrm{SH} 2$ scenario (room $\mathrm{RH}$ of $60 \%$ at 


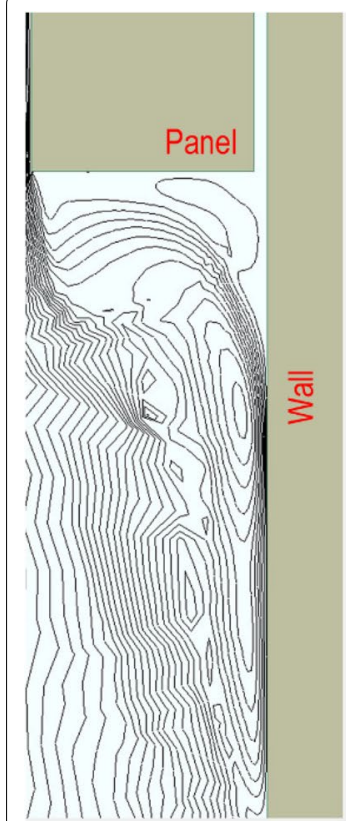

$\mathrm{S}=1,25 \mathrm{~mm}$

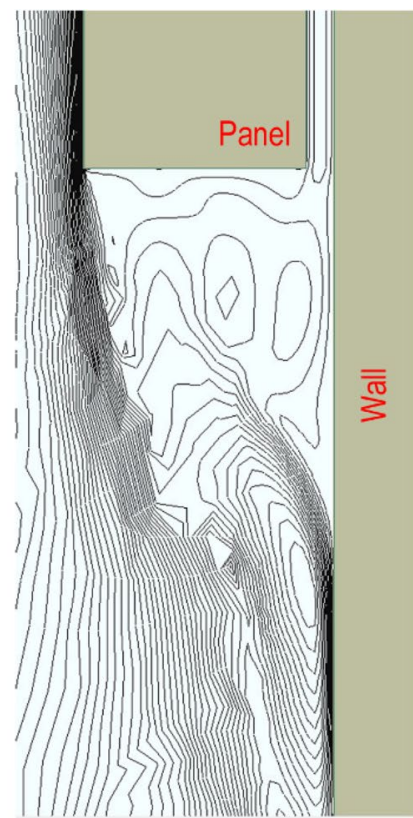

$\mathrm{s}=2,5 \mathrm{~mm}$

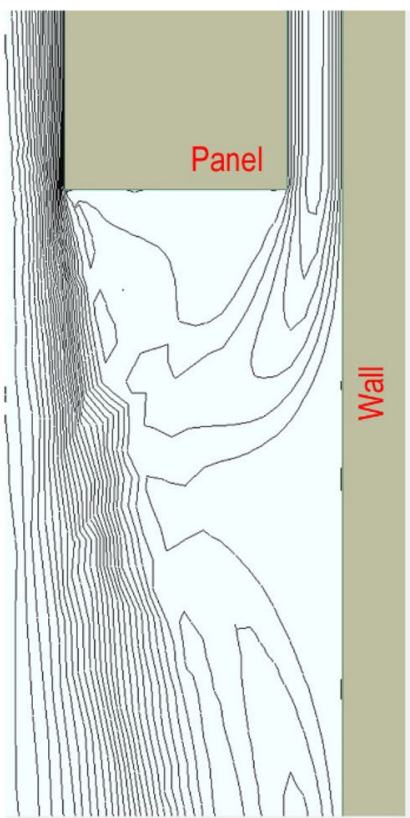

$\mathrm{s}=5 \mathrm{~mm}$

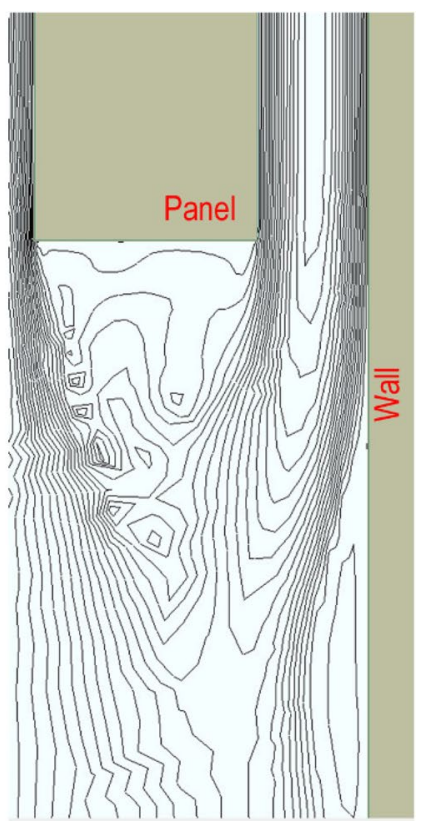

$\mathrm{s}=10 \mathrm{~mm}$

Fig. 11 Velocity isolines and eddys in channel outlet for panels $50 \mathrm{~cm}$ height and different widths

Table 4 Minimum "s" distances in scenario SH1

\begin{tabular}{|c|c|c|c|c|c|c|c|c|c|c|}
\hline \multirow[t]{2}{*}{ Panel height } & \multicolumn{2}{|c|}{$\begin{array}{l}\text { Minimum } \\
\text { Channel width }\end{array}$} & \multirow{2}{*}{$\begin{array}{l}\text { Distance } \\
\text { from panel } \\
\text { to ceiling } \\
\text { h1 }\end{array}$} & \multirow{2}{*}{$\begin{array}{l}\text { Room wall } \\
\text { height }\end{array}$} & \multicolumn{3}{|c|}{ Minimum temperature } & \multicolumn{3}{|c|}{$\begin{array}{l}\mathrm{RH} \text { at minimum Temp. } \\
\text { in scenario SH1 (52\% RH } \\
\text { in the room) }\end{array}$} \\
\hline & $s$ & $\mathrm{~s} / \mathrm{h}$ & & & Wall & Back & $\overline{\text { Front }}$ & Wall & Back & Front \\
\hline $\mathrm{m}$ & $\mathrm{mm}$ & ratio & $\mathrm{m}$ & m & ${ }^{\circ} \mathrm{C}$ & ${ }^{\circ} \mathrm{C}$ & ${ }^{\circ} \mathrm{C}$ & $\%$ & $\%$ & $\%$ \\
\hline 2 & 25 & 0.013 & 0.5 & 3 & 5.0 & 16.3 & 16.6 & 100 & 64.3 & 63.1 \\
\hline 1 & 20 & 0.020 & 1.0 & 3 & 6.0 & 17.4 & 18.1 & 100 & 59.9 & 57.2 \\
\hline 0.5 & 20 & 0.040 & 1.25 & 3 & 7.6 & 17.5 & 18.1 & 100 & 59.5 & 57.2 \\
\hline 2 & 40 & 0.020 & 3.50 & 6 & 6.5 & 16.5 & 16.8 & 100 & 63.5 & 62.2 \\
\hline 1 & 30 & 0.030 & 4.00 & 6 & 6.5 & 16.8 & 17.3 & 100 & 62.3 & 60.3 \\
\hline 2 & $90^{*}$ & 0.045 & 3.50 & 6 & 5.1 & 16.2 & 16.3 & 100 & 64.7 & 64.3 \\
\hline \multicolumn{11}{|c|}{ Isolated wall $2 \mathrm{~m}$ height with $60 \mathrm{~mm}$ EPS } \\
\hline 2 & 20 & 0.010 & 0.50 & 3 & 13.7 & 17.2 & 18 & 76.2 & 60.7 & 57.6 \\
\hline \multicolumn{11}{|c|}{ Back protected with Aluminium layer $0.5 \mathrm{~mm}$ width } \\
\hline 2 & 20 & 0.010 & 0.5 & 3 & 5.3 & 19.4 & 18.9 & 100 & 52.0 & 54.4 \\
\hline
\end{tabular}

If there is condensation in the wall $(100 \% \mathrm{RH})$, the minimum required gap between the Wall and the painting to avoid damages is $20 \mathrm{~mm}$

Room width $3 \mathrm{~m}$. Outside wall: limestone $\left(1.8 \mathrm{~W} / \mathrm{m}{ }^{*} \mathrm{~K}\right)$, width $40 \mathrm{~cm}$

$\mathrm{SH}=7.5 \mathrm{~g}$ water $/ \mathrm{kg}$ air; Dew Point $=9.7^{\circ} \mathrm{C}$; Room at $19.6^{\circ} \mathrm{C}$ and $52 \% \mathrm{RH}$; Outside at $-3{ }^{\circ} \mathrm{C}$

*In this case there is a $15 \times 5 \mathrm{~cm}$ cornice, $30 \mathrm{~cm}$ above the panel

$19.6{ }^{\circ} \mathrm{C}$ ) which comply with these conservation criteria. From these 16 cases we got the correct channel widths for all the models analysed.
Table 4 presents the 8 recommended minimum channel widths for the scenario SH1 and Table 5 the same figures for $\mathrm{SH} 2$. 
Table 5 Minimum " $s$ " distances in scenario SH2

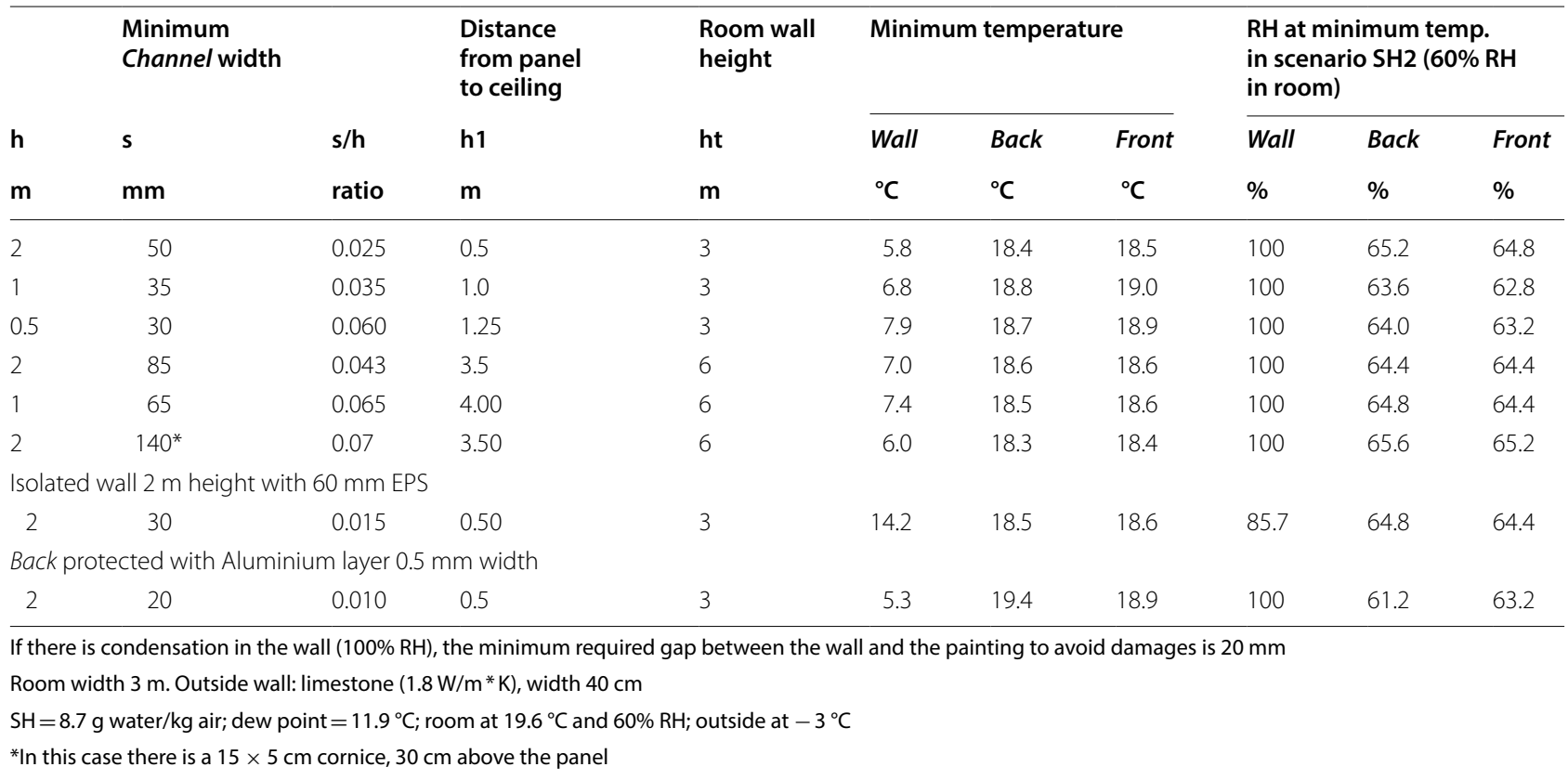

It shall be taken in account that changes of the Wall geometry, as cornices protruding above the painted wood panel, or other obstacles to the air flux can modify the recommended minimum separation distances, increasing them.

Attention: If the outside air temperature increases over $-3{ }^{\circ} \mathrm{C}$ and the $90 \% \mathrm{RH}$ is maintained, the $\mathrm{SH}$ of the infiltration and ventilations will rise. Therefore the inside room $\mathrm{SH}$ and $\mathrm{RH}$ will be increased and in this case the recommended channel width shall be increased according the foreseen channel temperatures and the new inside room $\mathrm{SH}$ value.

\section{Conclusions}

By means of a 2 dimensional CFD simulation of a heated room $\left(19.6^{\circ} \mathrm{C}\right)$ with a painted wood panel hung in the inside face of a non-isolated exterior wall $\left(-3{ }^{\circ} \mathrm{C}\right.$ in the outside face), we have obtained the temperatures, air velocities, and heat fluxes distribution in the channel between the wood panel and the exterior wall, for different wood panel heights, different channel widths, and different distances to the ceiling.

Based on the temperature data results in the wood panel Back and in the Wall, RH values have been obtained at the same locations and for two different $\mathrm{SH}$ scenarios $(7.5 \mathrm{~g}$ water $/ \mathrm{kg}$ air and $8.7 \mathrm{~g}$ water $/ \mathrm{kg}$ air) corresponding to a room at $52 \% \mathrm{RH}$ and $60 \% \mathrm{RH}$ respectively, which are within the normal range of conditions for a museum. From these values, we have established, for the foreseen $\mathrm{SH}$ scenarios, the minimum distances between the panel Back and the Wall required to avoid damages in the painted wood panel ( $\mathrm{RH}<66 \%$ in the panel Back) and a minimum of $20 \mathrm{~mm}$ in the case there is condensation in the Wall.

In addition, factors that affect temperatures distribution and heat fluxes in the channel have been analysed for series of discrete values in the normal range of use. In the case of a wood panel $50 \mathrm{~cm}$ high, these have been discussed in further detail in order to help understand the heat transfer modes involved in the situation.

The study of these factors that modify temperature distribution in both sides of the channel, such as the distance to the ceiling, the channel width, the possible eddy near the channel inlet or outlet, can be used as guidelines to be applied to other similar situations like other model dimensions or possible obstacles to the air flux in the Wall over the wood panel. As examples of this, the effects of a cornice in the Wall or the effects of an aluminium protection layer in the Back of the panel or an EPS $60 \mathrm{~mm}$ isolation in the Wall have been quantified to compare with cases without these peculiarities.

This simulation carried out with a commercial 2 dimensional CFD allows to extend the standard $20 \mathrm{~mm}$ recommendations for the distances between cold exterior walls and wood panel paintings to a more detailed recommendations for paintings hung on the walls in similar conditions. These recommendations do not entail neither financial costs nor climate variations in the museums and exhibition rooms and conservators can easily apply them. 
For the studied cases, Table 3, Back and Wall minimum temperatures and maximum RH values, and Additional file 1: Table S0, Back and Wall minimum temperatures at different heights, show how different these values are from those in the room or near other walls without panels hung on them. When conservators advise how to protect artistic wood panels hung in a poorly insulated peripheral wall, this fact shall be taken into account in addition to the recommendations in the EN standards [20-22].

\section{Supplementary information}

Supplementary information accompanies this paper at https://doi. org/10.1186/s40494-020-00376-1.

Additional file 1. Appendices.

\section{Abbreviations}

Wall: Inner face of the exterior wall; Back: Wood panel surface facing the Wall; Front: Wood panel surface facing the room; channel: Space between Back and Wall; s: Distance between wall and wood panel, channel width (m); $h$ :Wood panel height (m); s/h: Ratio channel width/wood panel height; $h t$ : Room height $(\mathrm{m}) ; \boldsymbol{h} 1$ : Distance from ceiling to wood panel upper border $(\mathrm{m}) ; \boldsymbol{V}$ : Velocity vector $(\mathrm{m} / \mathrm{s}) ; \mathbf{g}$ : Gravity acceleration vector $\left(\mathrm{m} / \mathrm{s}^{2}\right) ; \boldsymbol{l}$ : Buoyancy force vector $=-\mathbf{g}\left(\rho-\rho_{0}\right)=\rho_{0} \mathbf{g} \beta\left(T-T_{0}\right)$ if $\rho \Delta T \ll 1(\mathrm{~N})$; $u$ : Velocity horizontal component $(\mathrm{m} / \mathrm{s})$; $v$ : Velocity vertical component $(\mathrm{m} / \mathrm{s}) ; x$ : Horizontal coordinate $m$. Origin $x=0$ at inner wall (left side). (In Fig. 1); $y$ : Vertical coordinate $\mathrm{m}$. Origin $y=0$ at floor level. (In Fig. 1); t:Time (s); P: Pressure (Pa); $P^{\prime}$ Pressure correction (Pa); T: Temperature (K); $T_{0}$ : Reference temperature (K); Tw: Inner face temperature of the exterior wall $\left({ }^{\circ} \mathrm{C}\right) ; \mathrm{Tb}$ : Panel back Temperature $\left({ }^{\circ} \mathrm{C}\right)$; Ti: Air channel inlet average temperature, vertical velocity weighed $\left({ }^{\circ} \mathrm{C}\right)$; Tu: Turbulence intensity $(\%)=100 \mathrm{RMS}\left(\mathbf{v}^{\prime} / \mathbf{v}\right)$, being $\mathbf{v}^{\prime}$ fluctuations around the average velocity $\mathbf{v}$; Turb: Turbulence intensity average at $y$ height, velocity weighed in 20 channel points at the same height (\%); H: Enthalpy (J); $k$ : Kinetic energy $\left(\mathrm{m}^{2} / \mathrm{s}^{2}\right) ; k_{h}$ : Thermal conductivity $(\mathrm{W} / \mathrm{m} \mathrm{K}) ; \mathrm{c}_{\mathrm{p}}$ : Specific heat or Fluid heat capacity $(\mathrm{J} / \mathrm{kg} \mathrm{K}) ; \delta_{\mathrm{ij}}$ : Delta Kronecker $\left(\mathrm{i}=\mathrm{j}, \delta_{\mathrm{ij}}=1 \mathrm{i} \neq \mathrm{j}, \delta_{\mathrm{ij}}=0\right)$; Pr: Prandtl number $\operatorname{Pr}=\mu c_{p}, k_{h} ; \varphi$ : Generic property (velocity, temperature, and others); $\rho$ : Density $\left(\mathrm{kg} / \mathrm{m}^{3}\right) ; \rho_{0}$ : Reference density at $T_{0}\left(\mathrm{~kg} / \mathrm{m}^{3}\right) ; v$ : Kinematic viscosity $\left(\mathrm{m}^{2} / \mathrm{s}\right)=\mu / \rho ; v t$ : Computed turbulent kinematic viscosity $\left(\mathrm{m}^{2} / \mathrm{s}\right) ; \mu$ : Dynamic viscosity $\mathrm{N} \mathrm{s} / \mathrm{m}^{2}=\mathrm{kg} /(\mathrm{m} \mathrm{s}) ; \mu_{i}$ :Turbulent viscosity $\mathrm{N} \mathrm{s} / \mathrm{m}^{2}=\mathrm{kg} /(\mathrm{m} \mathrm{s}) ; \lambda: 2^{\circ}$ coefficient of viscosity (Lamé); $\varepsilon$ : Turbulent kinetic energy dissipation rate $\left(\mathrm{m}^{2} /\right.$ $\left.s^{3}\right) ; \omega$ :Turbulent kinetic energy frequency dissipation $\left(s^{-1}\right) ; \beta$ : Thermal expansion coefficient for perfect gases $=1 /$ Tunits $1 / \mathrm{K}_{i} \Gamma=\mu+\mu_{t}$ : units $\mathrm{N} \mathrm{s} /$ $\mathrm{m}^{2}=\mathrm{kg} /(\mathrm{m} \mathrm{s}) ; \Gamma_{h}$ : Heat diffusion coefficient $=\Gamma_{h}=\left(\frac{\mu}{\mathrm{Pr}_{\mathrm{r}}}+\frac{\mu_{t}}{\mathrm{Pr}_{\mathrm{t}}}\right) c_{p_{i}} ;$ : Magnitude to be computed in each cell; RH: Relative humidity (\%); SH: Specific or absolute humidity ( $\mathrm{kg}$ water $\left./ \mathrm{kg}_{\text {air }}\right) ; \mathrm{a}_{1}, \mathrm{a}_{2}, \beta_{1}, \beta_{2}, \sigma_{\mathrm{k} 1}, \sigma_{\mathrm{k} 2}, \sigma_{\omega 1}, \sigma_{\omega 2}, \sigma_{\beta}, a_{1}$ : Turbulence closure constants; $R r$ : Normalized Euclidian residual (general); Rm: Normalized Euclidian residual for mass.

\section{Acknowledgements}

Not applicable.

\section{Authors' contributions}

The order of authors in this paper has been set applying the sequencedetermines-credit approach (SDC). SF analyzed and interpreted the data resulting from software and carried out the calculation procedure and was a major contributor in writing the manuscript. GC-F designed the models and scenarios, provided conservation literature background and contributed in the discussion of results. CR-R collaborated in the analysis of data performing the graphics, images and tables and prepared the manuscript for final publication. MOF participated in the discussion of the results from the conservation point of view and contributed significantly in the writing process. All authors read and approved the final manuscript.

\section{Funding}

This research did not receive any specific grant from funding agencies in the public, commercial, or not-for-profit sectors.

\section{Availability of data and materials}

The datasets used and/or analyzed during the current study are available from the corresponding author on reasonable request.

\section{Competing interests}

The authors declare that they have no competing interests.

\section{Author details}

${ }^{1}$ Independent Researcher, Domènec Oristrell, 55. esc. C, 20-3aa, 08173 Sant Cugat Del Vallès, Spain. ${ }^{2}$ Arts and Conservation Department, Fine Arts Faculty, University of Barcelona, C/Pau Gargallo 4, 08028 Barcelona, Spain.

Received: 20 October 2019 Accepted: 27 March 2020

Published online: 10 April 2020

\section{References}

1. Mecklenburg MF. Micro climates and moisture induced damage to paintings. In: Padfield T, Borchersen K, editors. Museum microclimates conference. The National Museum of Denmark; 2007. p. 19-25.

2. Neuhaus E. A critical look at the use of HVAC systems in the museum environment. In: Ashley-Smith J, Burmester A, Eibl M, editors. Climate for collections. Standard and uncertainities. Munich: Archetype Publications and Doerner Institut; 2013. p. 117-26.

3. Padfield T, Berg H, Dahlstrøm N, Rischel A-G. How to protect glazed pictures from climatic insult. In: Vontobel R, editor. ICOM committee for conservation, 13thTriennal Meeting, Rio de Janeiro. London: James \& James; 2002. p. 80-5.

4. Raithby GD, Hollands KGT. Natural Convection. In: Rosenhow, WM, Hartnett, JP, Cho, YI, editors. Handbook of heat transfer. New York: McGrawHill; 1998. Vol. 3, chapter 4.

5. Bar-Cohen A, Rohsenow WM. Thermally optimum spacing of vertical, natural convection cooled, parallel plates. J Heat Transfer. 1984;106(1):116-23

6. Cadafalch J, Oliva A, Van der Graaf G, Albets X. Natural Convection in a Large channel with Asymetric Radiative Coupled isothermal Plates. J Heat Transfer. 2003;125(5):812-20.

7. Launder BE, Spalding DB. Mathematical Models of Turbulence. LondonNew York: Academic Press; 1972

8. Launder BE, Spalding DB. The numerical computation of turbulent flows. Comput Methods Appl Mech Eng. 1974:3(2):269-89.

9. Gameiro A. EasyCFD_G user's manual; 2014. http://www.easycfd.net. Accessed June 2017.

10. Gameiro A. A numerical procedure for 2D fluid flow simulation in unstructured meshes. In: Lopez-Ruiz R, editor. Numerical simulation-from brain imaging to turbulent flows. IntechOpen; 2016. https://www.intec hopen.com/books/numerical-simulation-from-brain-imaging-to-turbu lent-flows/a-numerical-procedure-for-2d-fluid-flow-simulation-in-unstr uctured-meshes. Accessed June 2017.

11. Gameiro A. A 2D software system for expedite analysis of CFD problems in complex geometries. Comput Appl Eng Educ. 2016;24(1):27-38.

12. Gameiro A. A versatile software tool for the numerical simulation of fluid flow and heat transfer in simple geometries. Comput Appl Eng Educ. 2010;18(1):14-27.

13. Gameiro A, Villar JA. Numerical simulation of the airflow around airfoils for small wind turbines applications. In: Avilez-Valente P, Carvalho E, Silva Lopes A, editors. V Conferência Nacional de Mecânica dos Fluidos, Termodinâmica e Energia, MEFTE 2014. Porto: AMTAC, FEUP; 2014. p. 21-26.

14. Gameiro A, Alé JAV, Ferreira A, Da G, Simioni S, Calgaro V. Stall and Pos-Stall of airfoils for small wind turbines: numerical and experimental analysis. In: 14th international conference on wind engineering (ICWE14). Porto Alegre, 2015. http://www.icwe14.org/. 
15. Grau-Bové J, Mazzei L, Strlic M, Cassar M. Fluid simulations in heritage science. Herit Sci. 2019;7:16. https://doi.org/10.1186/s40494-019-0259-9.

16. Michalski S. Climate guidelines for heritage collections: where we are in 2014 and how we got here. In: Stauderman S, Tompkins WG, editors. Proceedings of the Smithsonian Institution. Summit on the Museum Preservation Environment, 13th-14th March 2013. Washington D.C: Smithsonian Institution Scholarly Press; 2016. p. 7-33.

17. Erhardt D, Tumosa CS, Mecklenburg MF. Applying science to the question of museum climate. In: Padfield T, Borchersen K, editors. Museum Microclimates. Copenhaguen: National Museum of Denmark; 2007. p. 11-8.

18. Michalski S. The ideal climate, risk management, the ASHRAE chapter, proofed fluctuations, and towards a full risk analysis model. In: Contribution to the Experts roundtable on sustainable climate management strategies, held in April 2017 in Tenerife, Spain. The Getty Conservation Institute; 2007. https://www.getty.edu/conservation/our_projects/scien ce/climate/paper_michalski.pdf. Accessed 13 June 2017.

19. Museums, galleries, archives and libraries. In: Owen MS, editor. ASHRAE Handbook-HVAC Applications. Atlanta: ASHRAE-American Society of Heating, Refrigerating and Air Conditioning Engineers Inc.; 2011. Chapter 23, p. 23-1-23-2.

20. EN 15757 Conservation of cultural property — Specifications for temperatures and relative humidity to limitate the climate-induced mechanical damage in organic hygroscopic materials; 2010. European Committee for Standarisation, Brussels.

21. EN 15759-1 Conservation of cultural property -Indoor climate-Part 1: guidelines for heating churches, chapels and others places of worship. Brussels: European Committee for Standarisation; 2011.

22. EN 15759-2 Conservation of cultural property -Indoor climate-Part 2:ventilation in historic buildings and to protect collections. 2018. Brussels: European Committee for Standarisation; 2018.

23. Camuffo D. Microclimate for cultural heritage. Conservation, restoration and maintenance of indoor and outdoor monuments. Amsterdam: Elsevier; 2019
24. Camuffo D, Pagan E, Rissanen S, Bratasz L, Kozlowiski R, Camuffo M, della Valle A. An advanced church heating system favourable to artworks: a contribution to European standarisation. Journal of Cultural Heritage. 2010;11:205-19.

25. Bratasz L. Allowable microclimate variations in museums and historical buildings: review the guidelines. In: Burmester A, Eibl M, editors. AshleySmith J. Climate for collections. Standard and uncertainities. Munich: Archetype Publications and Doerner Institut; 2013. p. 11-9.

26. Bratasz L. Aceptable and not acceptable microclimate variability: the case of wood. In: Camuffo D, Fassina V, Havermans J, editors. Basic environmental mechanisms affecting cultural heritage. Florence: Nardini; 2010. p. 49-58.

27. Broström T, Vyhlídal T, Simeunovic G, Klenz Larsen P, Zítek P. Evaluation of different approaches of microclimate control in cultural heritage. In: Ashley-Smith J, Burmester A, Eibl M, editors. Climate for collections. Standard and uncertainities. Munich: Archetype Publications and Doerner Institut; 2013. p. 105-15.

28. Neuhaus E, Schellen HL. Humidistat controlled heating and ventilation systems to create preservation conditions in historic buildings in the Dutch climate. In Seppänen O, Säteri J, editors. Proceedings of the 9th Clima World Congress Wellbeing Indoors. Volume 9. Helsinki: Finvac; 2007.

29. Schijndel van AWM. Integrated heat air and moisture modeling and simulation. Eindhoven: Technische Universiteit. https://doi.org/10.6100/ ir622370.

\section{Publisher's Note}

Springer Nature remains neutral with regard to jurisdictional claims in published maps and institutional affiliations.

\section{Submit your manuscript to a SpringerOpen ${ }^{\circ}$ journal and benefit from:}

- Convenient online submission

- Rigorous peer review

- Open access: articles freely available online

- High visibility within the field

Retaining the copyright to your article

Submit your next manuscript at $\boldsymbol{\nabla}$ springeropen.com 